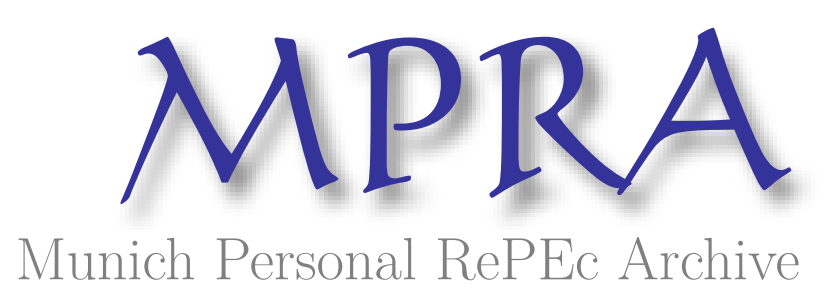

\title{
Exchange Rate Trends and Export Performance in Nigeria: A Descriptive Approach
}

OWURU, Joel and FARAYIBI, Adesoji

University of Ibadan, Centre for Allied Research and Economic Development

15 June 2016

Online at https://mpra.ub.uni-muenchen.de/74158/

MPRA Paper No. 74158, posted 01 Oct 2016 15:48 UTC 


\title{
Exchange Rate Trends and Export Performance in Nigeria: A Descriptive Approach
}

\author{
Joel Ede OWURU ${ }^{1}$ and Adesoji Oladapo FARAYIBI ${ }^{2}$
}

\begin{abstract}
This study examines the exchange rate trends and export performance in Nigeria between 19702015 using a descriptive approach. Particularly, the study emphasizes the impacts of exchange rate volatility on export demand in the country. The choice of this period is underscored by the fact that the starting date predates the era of the structural adjustment program (SAP) which is often described as the good days where agricultural and non-oil exports tremendously increased. Again, this date coincides with period when the external trade and exchange rate were indeed liberalized. Findings from descriptive analysis show that despite the policy pronouncements in the period covered, exchange rate volatility greatly affected export performance in Nigeria, in particular, the volume of export demand. The study recommends a deliberate exchange rate policy action that will have good implication for export growth in Nigeria.
\end{abstract}

Keywords: Exchange Rate Trend, Export Performance, Nigeria, Descriptive Approach, Demand

\section{INTRODUCTION}

The speedy nature of globalization in the contemporary times has made all countries of the world to live interdependently on one another. Thus, no country of the world is entirely an island of itself without having anything to do with other countries. In this case, globalization of trade has increasingly rendered the world borderless. This scenario has widened the consumption choice bundles of consumers in various countries because more goods and services are available to them as a result of international trade. In this view, trade, unarguably is one of the vital sources of growth and development. The state of demand for Nigeria's exportable products in the international market in particular is an injection into the economy as financial resources are received into the domestic economy; hence it is responsible for increasing the level of external reserve of the country.

In the periods of 1960s and 1970s, large proportions of Nigerian exports were dominated by the agricultural sector and it was a major source of foreign revenue. Nigeria was recognized as the major exporter of groundnut, cocoa, rubber and other agricultural products. However, this trend has changed in favour of oil. The revenues expected from the proceeds from exports are strongly affected by the incessant nature of the changes in the exchange rate. Unpredictable changes in exchange rate, which is normally dubbed as exchange rate volatility, have pervasive effects on the performances of the export sector of the country.

\footnotetext{
${ }^{1}$ Department of Economics and Centre for Econometrics \& Allied Research (CEAR), University of Ibadan, Ibadan, Nigeria. Corresponding Author: owurujoel@yahoo.com

${ }^{2}$ Nigerian Institute for Social and Economic Research (NISER) \& Centre for Allied Research \& Economic Development, Ibadan.
} 
About three decades ago, the focus of Nigeria, like other countries in the Sub-Saharan Africa was on Import Substitution Industrialization (ISI) where increased production of goods that were largely imported were encouraged as a means for achieving high level of economic growth. Considering the fact that the economy of Nigeria was predominantly agrarian, the policy of ISI was to encourage the productive capacity of the agricultural sector of the economy with the realization that exports spur economic growth. the growth of the economy of Nigeria was encouraging as export volumes of products like groundnuts, cocoa, rubber and other agricultural produces were high as a result of the fact that exchange rate of the naira relative to other currencies of the trading partners of Nigeria appreciated.

However, with the Bretton wood system, exchange rates of various developing countries, including Nigeria were encouraged to be devalued as part of the Structural Adjustment Programme (SAP) recommended by the International Monetary Fund (IMF) and World Bank (IBRD) as one of the best economic policies if not the best for economic growth. With this development, unpredictable nature of volatilities in exchange rate, oil prices and commodity prices at the international markets which imply low profitability from exports were the consequences. Thus there have been dismal performances of both agricultural and the oil sector due to fluctuations of prices, which are believed to be caused by incessant volatilities of exchange rate at the international market. In view of these issues raised, the burgeoning research questions which this study will address include: What is the extent of the volatility of the exchange rate of the naira? Is there the occurrence of volatility clustering in the behaviour of the Nigerian naira/dollar exchange rate parity? What is the trend of the performance of both oil and non-oil exports in Nigeria? What is the trend of the behaviour of exchange rate of the naira in relation to the US dollar? Thus the main objective of this paper is to examine the impact of the exchange rate volatility on export demand in Nigeria.

The rest of the paper is as follows: section two is the review of literature and the gaps the study intends to fill. Section three is the descriptive analysis and interpretation of exchange rate volatility and export trade nexus while section four gives the conclusion and recommendations.

\section{EMPIRICAL LITERATURE}

The early empirical work on the effect of exchange rate variability and trade surveyed in the IMF (1984) study did not yield consistent results, with many studies yielding little or no support for a negative effect. For example, the early work by Hooper and Kohlhagen (1978) utilized the model of Ethier (1973) for traded goods and derived equations for export prices and quantities in terms of the costs of production reflecting both domestic and imported inputs, other domestic prices, domestic income, and capacity utilization. Exchange rate risk was measured by the average absolute difference between the current period spot exchange rate and the forward rate last period, as well as the variance of the nominal spot rate and the current forward rate. They examined the impact of exchange rate volatility on aggregate and bilateral trade flow data for all G-7 countries except Italy.

In terms of the effect of volatility on trade flows, they found essentially no evidence of any negative effect. Cushman (1983) used a model similar to that of Hooper and Kohlhagen (1978) but extended the sample size and used real as opposed to nominal exchange rates. Of fourteen 
sets of bilateral trade flows between industrial countries, he found a negative and significant effect of volatility for six cases. Finally, the IMF (1984) used a simplified version of Cushman's model to estimate bilateral exports between the G-7 countries from the first quarter of 1969 to the fourth quarter of 1982, with real GNP, the real bilateral exchange rate, relative capacity utilization, and variability measured as the standard deviation of the percentage changes in the exchange rate over the preceding five quarters. In only two cases did variability have a significantly negative coefficient, while positive and significant coefficients were found in several cases.

McKenzie (1999) surveyed a large number of empirical papers on the topic, most of which appeared after the IMF study. He stressed the point made above that at a theoretical level, models have been constructed which lead to negative or positive effects of variability on trade, and that a priori there is no clear case that one model is superior to another. His survey of the empirical work led to the same mixed picture of results, with many studies finding no significant effect, or where significant, no systematic effect in one direction or the other. He found, however, that the most recent contributions to the literature have been more successful in obtaining a statistically significant relationship between volatility and trade, which he attributes to more careful attention to the specification of the estimation technique.

Recent works including Frankel and Wei (1993), Wei (1999), and Tenreyro (2003) among others employed the gravity model and found some significant evidence of a negative relationship between exchange rate variability and trade. The work by Dell'Ariccia (1999) provided a systematic analysis of exchange rate volatility on the bilateral trade of the 15 EU members and Switzerland over the 20 years from 1975 to 1994, using four different measures of exchange rate uncertainty: the standard deviation of the first difference of the logarithm of the monthly bilateral nominal and real (CPI) exchange rate, the sum of the squares of the forward errors, and the percentage difference between the maximum and the minimum of the nominal spot rate. In the basic regressions, exchange rate volatility had a small but significantly negative impact on trade.

Rose (2000) also employed the gravity approach and uses a data set of 186 countries to measure the effect of currency unions on members' trade and test for the effects of exchange rate volatility on trade. He found a small but significant negative effect: reducing volatility by one standard deviation ( 7 percent) around the mean ( 5 percent) would increase bilateral trade by about 13 percent. The findings of Tenreyro (2003) were however contrary to that of Rose. She found a small effect: reducing volatility from its sample mean of about 5 percent to zero results in an increase in trade of only 2 percent. Other empirical studies on the effects of exchange rate volatility on disaggregated trade flows like Broda and Romalis (2003) found that volatility decreases trade in differentiated products relative to trade in commodities. They found that eliminating all real exchange rate volatility would increase trade in manufactures by less than 5 percent and total trade by less than 3 percent.

The empirical results of Bacchetta and van Wincoop (2000) suggested that under certain regularity conditions, the exchange rate volatility lead to increase trade flows. Baaka, (2004) used the Japanese export data to investigate exchange rate volatility-export nexus and found a negative and significant long-run relationship between exports and exchange rate volatility in South Korea, Singapore and Thailand, and a positive but insignificant short-run relationship. For Indonesian, Rahutami and Kusumastuti (2007) found that volatility had a significant effect on trade only in the long run, but not in the short run, and it only appeared in some Indonesian trade 
partners. Boug and Fagereng (2010) found no evidence suggesting that export performance of Norwegian firms has been significantly affected by exchange rate uncertainty. That is exchange rate volatility showed neutral effects on export performance of Norway.

Klein (1990) tested the impact of exchange rate uncertainty on U.S. monthly bilateral sectoral exports to six major industrial countries, and finds that exchange rate volatility negatively affects agricultural exports, far more than trade volumes from other sectors. Pickard (2003) indicated that exchange rates adversely affected U.S. agricultural exports to developing countries, underscoring the importance of exchange rate risk in trading behavior of developing countries. Recently, Cho, Sheldon and McCorriston (2002) found that the negative impact of uncertainty on agricultural trade has been more significant compared to other sectors for a sample of bilateral trade flows across ten developed countries. Using monthly data disaggregated by markets of destination and sectors, de Vita and Abbott (2001) found that UK exports to the 14 EU countries, in aggregate and across sectors, are largely unaffected by short-term exchange rate volatility. In contrast, Langley et al. (2000) found that exchange rate volatility had a positive impact on Thailand's poultry exports, but no statistically significant effect on aggregate exports.

Akhtar and Hilton (1984), using the sample period of 1974 to 1981 and Ordinary Least Square (OLS) method to study the effects of exchange rate uncertainty on German and U.S. Trade, found that exchange rate volatility had a negative effect on trade. Similarly, Peree and Steinherr (1989) in their study on exchange rate uncertainty and foreign trade with sample period of 1960 to 1985 using OLS observed that there was negative effect of exchange rate uncertainty on foreign trade. Again, Belenger et al. (1988) conducted a research on exchange rate variability and trade flows using sectoral estimates for the US-Canada using the instrumental variable estimate and submitted that variability of exchange rate had significant and negative effect on the trade flows.

In the process of determining the level of relationship and impact of volatility of the exchange rates on international trade, Caballero and Corbo (1989) studied the effect of real exchange rate uncertainty on exports using Ordinary Least Square and instrumental variable. They found out that volatility of exchange rate have negative effect on export performance. Bini-Smaghi (1991) examined how exchange rate variability affects trade by using Ordinary Least Square method and found that exchange rate variability had significant and negative effect on trade flows. Furthermore, Doganlar (2002), used error correction and cointergration method to explored the impact of exchange rate volatility on export. It was observed that the volatility of exchange rate had negative effect on exports. Vergil (2002) conducted a study to determine the effect of volatility of exchange rate using standard deviation method and arrived at a conclusion that exchange rate volatility had negative effect on the export performance.

Asseery and Peel (1991) combined ordinary least square method and error correction model to investigate the effects of exchange rate volatility on exports of some selected European countries and discovered that volatility of exchange rate had significant and positive effect on exports except UK. McKenzie and Brooks (1998) also achieved the same result using Ordinary Least Square in their study of exchange rate volatility on German-US trade flows. Again, McKenzie (1998) studied the Impact of exchange rate volatility on Australian Trade Flows, and found that exchange rate volatility had negative effect on the trade flows of Australian using the ARCH method.

For Zambia, between the period of 1965 and 1999, Anthony (2008) used a generalized autoregressive conditional heteroscedasticity $(\mathrm{GARCH})$ to measure real exchange rate volatility 
and found that exchange rate volatility depresses exports in both the short-run and long-run. Using similar methodology, Lee and Saucier (2005) studied the relationship between exchange rate instability and trade integration by examining the relationship between exchange rate volatility and export trade with ARCH-GARCH model and found that there exist negative relationship between the instability of exchange rate and trade integration.

In Nigeria, similar studies on this issue have been carried out. Obiora and Igue (2006) examined exchange rate volatility and U.S-Nigeria trade flows and they showed that exchange rate volatility of the domestic currency had a negative and significant effect on Nigeria's exports to the United States of America. Akinlo and Adejumo (2014) examined the impact of exchange rate volatility on non-oil exports in Nigeria and found a statistically negative effect of exchange rate volatility on non-oil exports in the long run. In a similar vein, Omojimite and Akpokodje (2010) investigated Nigeria's trade performance during the period 1986-2007 and found small positive effect of exchange rate reforms on non-oil exports through the depreciation of the value of the country's currency (naira).

Also, in the context of Nigeria, Aliyu (2009) employed standard deviation measure of exchange rate volatility based on quarterly observation and examined the impact of exchange rate volatility on non-oil export flows in Nigeria between 1986 and 2006. He revealed that exchange rate volatility decreased non-oil exports in Nigeria. Olowe (2009) investigated the volatility of Naira/Dollar exchange rates in Nigeria using several variants of Generalized Autoregressive Conditional Heteroskedasticity (GARCH) models. He used monthly data over the period January 1970 to December 2007 and found that all the GARCH family models indicated that volatility was persistent and reported similar evidence for the fixed exchange rate and managed float rate regimes. Yinusa and Akinlo (2008) also applied error correction model to study the impact of real effective exchange rate volatility on the performance of non-oil exports of Nigeria using quarterly data spanning from 1986-2008 and found that at volatility in exchange rate significantly caused positive impact on export performance.

\subsection{Gap in Previous Studies and Value added}

Despite these studies, it was observed that most studies on exchange rate volatility focused on developed countries and Asian economies (Akinlo \& Adejuwon, 2014) and so, there is only little or rudimentary empirical evidences on volatility of exchange rate that exist for Nigeria. For instance, Akinlo and Adejumo, (2014) seems to be the existing study that considered non-oil export in their examination of the impact of exchange rate volatility on trade volume in Nigeria.

This study will add value to literature by embarking on a robust analysis by expanding its scope (1970-2015), unlike other studies like Akinlo and Adejumo that spanned only from 1986-2008. This is necessary because various issues before the SAP period of 1986 and other post 2008 issues in exchange rate dynamics and export performance could be examined within the chosen period for the study. Thus, the findings of this study are hoped to be more revealing and significant as it will reveal important policy implications of exchange rate volatility on both oil and non-oil export. Evidence from these studies will also serve as a guide for other researchers to expand more on related research issues. 


\section{DESCRIPTIVE ANALYSIS AND DISCUSSIONS}

\subsection{Exchange Rate Dynamics in Nigeria}

Since the collapse of the Bretton Woods system (and the adoption of the floating exchange rate regime) in 1973, the exchange rates have been highly volatile in both developed and developing countries and in most developing countries. In Nigeria, exchange rate management has undergone significant changes over the past five decades. In the 1960s, Nigeria operated a fixed dollar in addition to restrictions on imports through strict administrative controls on foreign exchange. In 1978, the Nigerian monetary authorities pegged the naira to a basket of 12 currencies of her exchange rate regime fixed at par with the British pound and later the American major trading partners. The sharp fall in international oil price and consequent decline in foreign exchange receipts in the early 1980s were such that the economy could not meet its international financial commitments, and to mitigate the challenges, the stabilization act of 1982 was implemented which led to accelerated depreciation of the naira. Failure of the Stabilization Act to address the economic problems (unpaid trade bills and accumulation of payment arrears consequent on the sharp fall in oil price) led to the adoption of the Structural Adjustment Programme (SAP) in 1986, aimed amongst others at the realization of a viable and realistic exchange rate, through a flexible arrangement. The adoption of the flexible exchange rate regime produced a significant volatility and uncertainty in the exchange rate of the naira against US dollar as indicated in Figure 1.

\section{Figure 1: Average Annual Official Exchange Rate of the Naira (N/US\$1.00)}

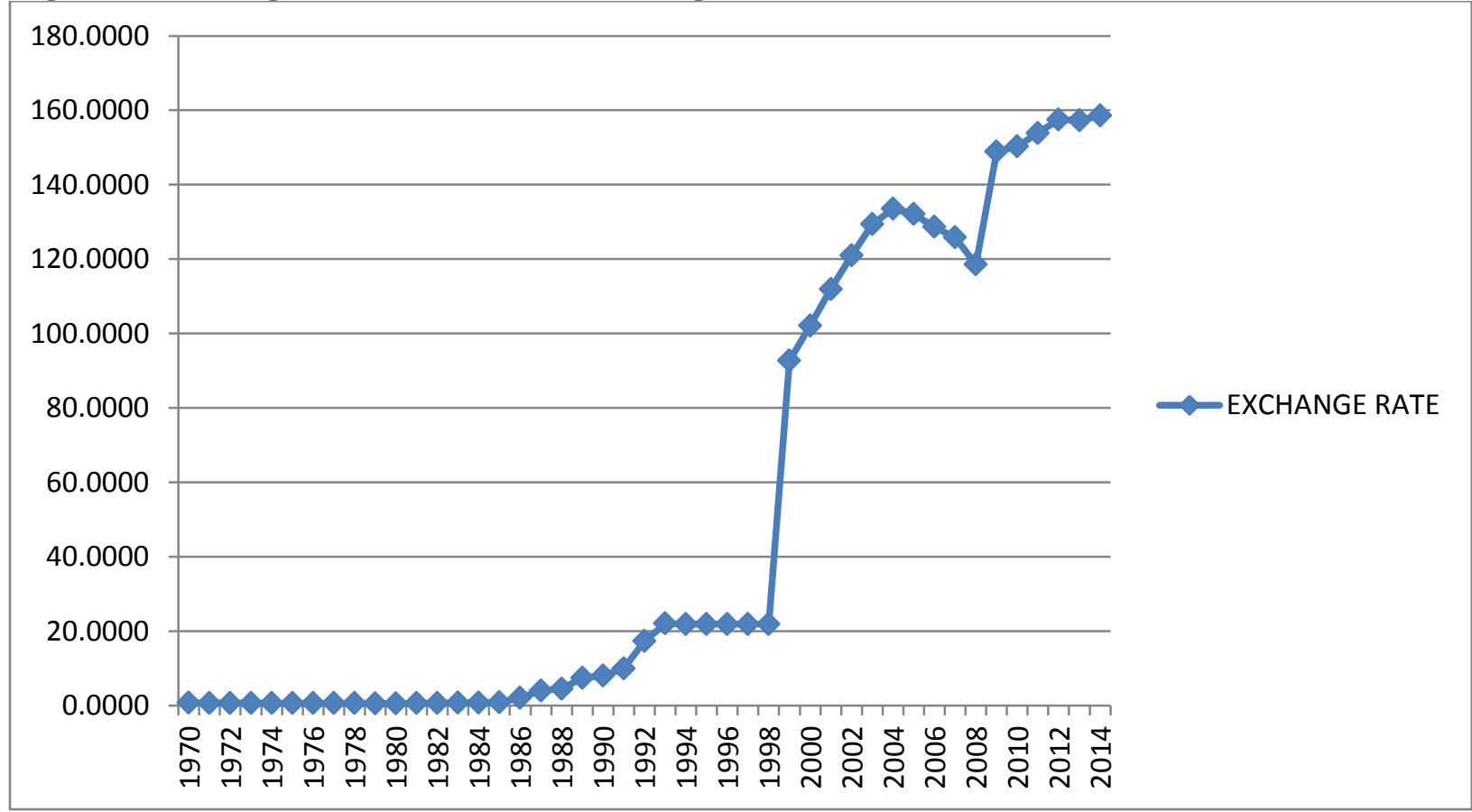

Source: Computed by the authors from the CBN statistical bulletin, 2014 edition.

It can be observed from Figure 1 that there was relative stability in the dynamics of exchange rate from 1970 to 1985 with the highest exchange rate value of 0.8938 . By implication, less than one naira was exchanging for one US dollar. This period was characterized with the adoption of fixed exchange rate regime which has led to the observed stability. Right from 1971 and the breakdown of the Bretton Wood system, the Nigerian government jettison the British pound 
starling and the adoption of the US dollar as a reference currency for the purpose of determining the exchange rate of the Nigerian pound. In January 1973, the Nigeria pound was replaced with the naira as the domestic currency and its value in par with the US dollar was $\# 0.65 /$ US\$. To increase the level of external sector competitiveness in Nigeria, the Central Bank of Nigeria $(\mathrm{CBN})$ adopted a strategy to use the country's export performance to stabilize the exchange rate of naira against the dollar in 1974. Thus, the increase in oil prices in the international market within these periods led to increased appreciation and stability of the exchange rate of the naira. The policy was not sustained for a long period due to the first oil glut between 1976 and 1978 which led to tightening or re-fixing of the naira exchange rate to basket of currencies of other trading partners of Nigeria with a consequent reduction in external reserves.

The periods of the fixed exchange rate regime which made the exchange rate to be relatively stable however induced an overvaluation of the naira and significant distortions in the economy, which gave rise to massive importation of finished goods with its adverse consequences on domestic production, balance of payments position and the nation's external reserves. These problems, amongst others informed the adoption of the flexible exchange rate regime within the context of the Structural Adjustment Programme (SAP) in 1986. Within the context of the SAP, the CBN adopted a Second-tier Foreign Exchange Market (SFEM) in 1986 under Structural Adjustment Programme (SAP; to establish a realistic exchange rate for the naira and all official transactions were conducted at a fixed pre-SFEM rate, while private sector transactions were based on the market rate. However in 1987, the system merged into a single regime to mitigate the structural distortions in the economy, and despite the flexible regime, the exchange rate of naira depreciated ${ }^{3}$ sharply from annual average rate of \#2.02/US\$1 in 1986 to \#17.30/US\$1 in 1992 and \#22.05/US\$1 in 1993.

Furthermore, exchange rate of naira to US dollar was stable at \#21.89/US\$1 between 1994 and 1998. This pegging was consequent upon the fact that the CBN has introduced the Dutch Auction System to curb excessive demand in 1990 as Bureau de Change (BDCs) was observed to service small scale foreign exchange end-users only. These observed problems led the bank to move from the initial flexible or deregulated exchange rate system in 1992 to a fixed system in 1994 when the naira was pegged at N21.89/US\$1 till 1998. It can be seen again from the chart above that at the dawn of democratic rule in 1999, there was a sporadic rise in the level of depreciation of the exchange rate when it jumped from \#21.89 in 1998 to \#92.69 in 1999. The currency subsequently depreciated from \#92.69 in 1999 to \#133.5 in 2004. Some of the key policy events that underline these depreciation include the fact that the foreign exchange committee which was set-up to allocate scarce foreign exchange resources in 1995 failed, hence the prevailing macroeconomic conditions led to further devaluation of the naira and the dual exchange rate system was re-introduced in 1995 under a "Guided Deregulation' to address the substantial depreciation of the naira and to manage the country's external resources.

Again, in 1999, the foreign exchange market was fully deregulated to reduce the rent seeking behaviours and establish some level of macroeconomic stability. The Inter-Bank Foreign Exchange Market (IFEM) then established in October 1999 and was conducted daily with banks as major participants and the $\mathrm{CBN}$ as a moderator. Despite these policy efforts, the chart showed

\footnotetext{
${ }^{3}$ Depreciation in this case is when higher volume of naira goes for one US dollar.
} 
that there was a constant rise in the depreciation rate of naira from 1999 to 2004. It can be observed further from Figure 1 that the naira exchange rate appreciated against US dollar from $\# 132.15 /$ US $\$ 1$ in 2005 to \#118.57/US $\$ 1$ in 2008. However, the trend changed with a reversed depreciation of the exchange rate of naira at \#148.88 as against \#118.57 in 2009. The peak of the period of global financial crises in 2009 till the recent episode of oil price volatility or shocks at the international oil market has contributed to the recent rise in the depreciation rate of naira against dollar. In all, it can be observed critically that variations in the volatility of exchange rate occurred within the period under study in the various regimes adopted by the Nigerian government in the management of her foreign exchange rate.

\subsection{Export Performance in Nigeria}

Exportation of goods and services is required by any economy to enhance its revenue and usher in economic growth and development. It is therefore crucial for economic progress and this has informed the idea of export-led growth. The performance of export is seen as catalysts for overall development and increases the earnings of the country thereby creating an avenue for growth by raising the national income of the country. One of the major macroeconomic objectives of an economy is to attain full employment and export stands as a driver to its achievement because higher demand for exports will require more production which will in turn lead to creation of more employment opportunities in the country. Export commodities in Nigeria can be classified into oil and non-oil exports. Prior to independence, agriculture was the major component of exports and contributed immensely to Nigerian export earnings. But the advent of crude oil production especially; the oil boom of 1970s brought with it attendant fundamental changes in the Nigerian economy such that attention was diverted only to the oil sector while the agricultural sector was neglected. This scenario is represented in Figure 2 and Table 1 in the appendix where the performance or the share of Oil export in total export outweighs that of NonOil export.

Figure 2: Relative percentage share of Oil and Non-oil exports in total Exports (1970-2014)

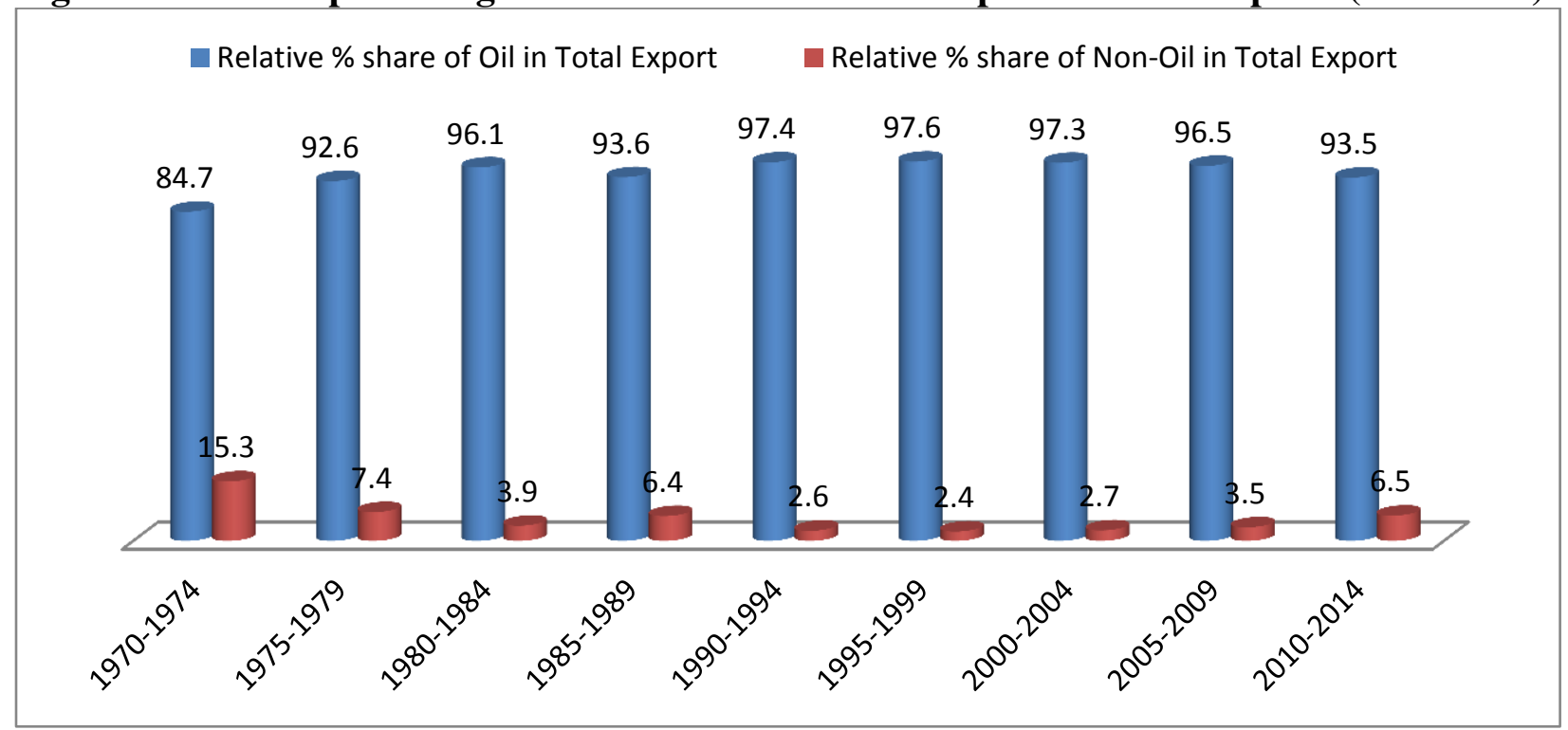

Source: Computed by the authors from the CBN statistical bulletin, 2014 Edition. 
It can be observed from the results in Figure 2 that the performance of Oil export steadily increased from $84.7 \%$ in $1970-1974$ fiscal years to $96.1 \%$ in $1980-1984$, it fluctuated down to 93.6\% in 1985-1989 fiscal periods, but rose from $97.4 \%$ in 1990-1994 to $97.6 \%$ in 1995-1999 periods. After the emergence of a democratically elected government in 1999, Oil export performance still towered high from 97.3\% in 2000-2004 fiscal years to 96.5\% in 2005-2009 and fell slightly by $3 \%$ in 2010-2014 fiscal years. On the other hand, the results show that the contribution of Non-Oil export in Total Exports has been so meager with average performance of less than $10 \%$, except for the early years (1970-1974) where the discovery of oil was still fresh. In this case, the performance of the non-oil sector amounted to $15.3 \%$. The SAP policy in 1986 was expected to induce high performance of the agricultural and other non-oil sector; however, the effects were not sustained as total non-oil share in total export reduced from $6.4 \%$ in $1985-$ 1989 to $2.6 \%$ and $2.4 \%$ in $1990-1994$ and $1995-1999$ respectively. This paradigm shift from Non-Oil to Crude oil made Nigeria to depend heavily on petroleum as the main source of foreign exchange earnings and government revenue.

There was a surge in the value of Oil export between 1994 and 1995 where the highest peak of the share of Oil in total export was put at 97.6\%. However, declines occurred from the millennium up to the $21^{\text {st }}$ century as the share of Oil in total export slightly decreased from 97.3\% to $93.5 \%$ between 2000-2004 and 2005-2014 respectively. These declines led to both internal and external disequilibrium which made industries to experience difficulties to import necessary inputs, and the public sector could not generate sufficient revenue, especially with the occurrence of oil price shocks and volatilities in the international energy market which is unfavourable to Nigeria due to institutional problems. Again, the recent shift in the attention or demand for Nigerian crude oil by the American is responsible for the observed declined in the proportion of Oil export (See figure 3 as evidence in this regard).

Figure 3: Percentage Distribution of the share of Crude oil Exports by the EAAA (2009-2013)

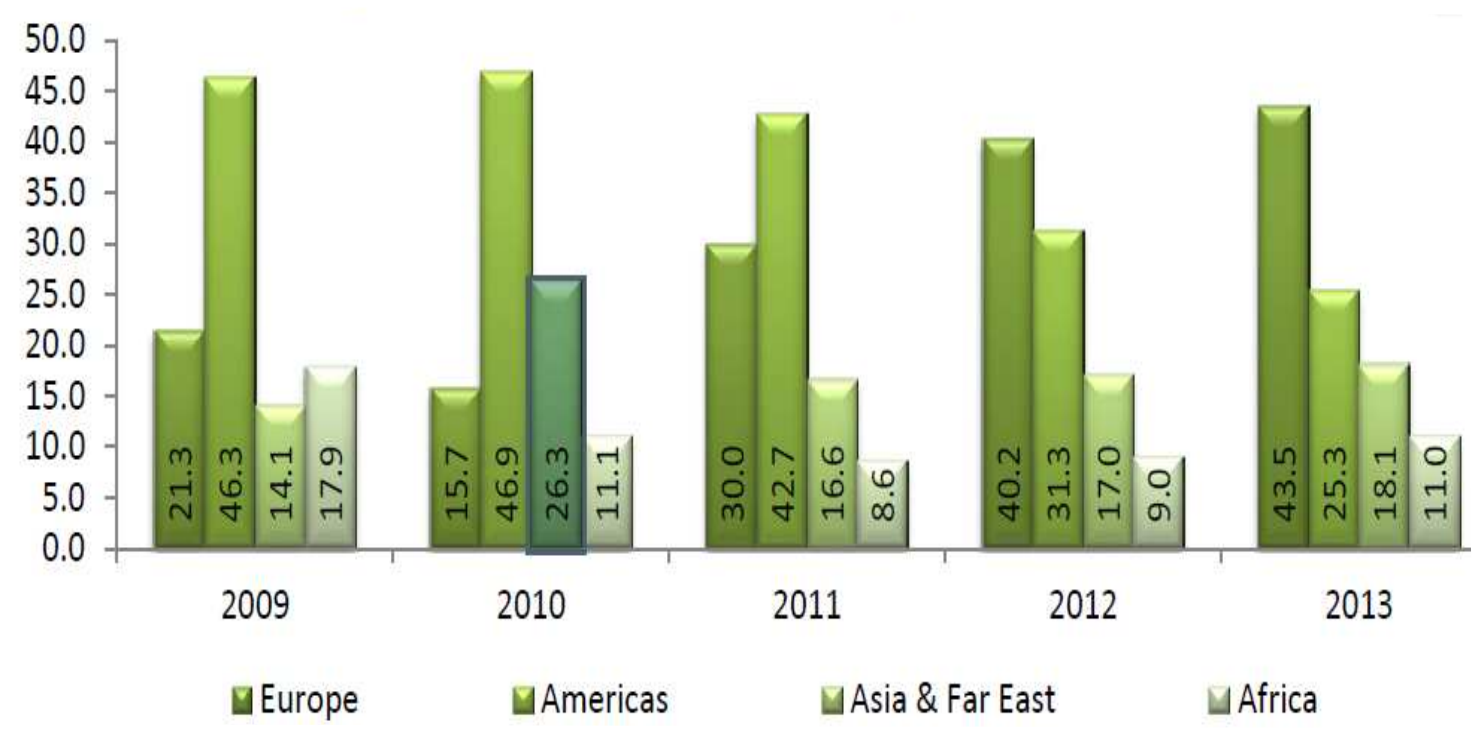

Source: Adopted from CBN, 2013 Annual Report.

Figure 3 revealed that within 2009 and 2010, there was increased in the demand for Nigerian crude oil by the Americans, however, the trend change from 2011 till 2013 where the percentage 
of the share of the demand for Nigerian crude oil by the American declined from $42.7 \%$ in 2011 to $25.3 \%$ in 2013. From the direction and trend of crude oil exports between 2009 and 2013 as depicted in the Figure 3, the share of crude oil exports to Africa remained the least compared to Europe, America, Asia and Far East (EAAA).

Judging from the aggregate perspective, it is shown clearly in Figure 4 that the contribution of total export (both oil and non-oil) to Gross Domestic Product (GDP) is not stable. The share of total export in GDP averaged $18.72 \%$ within the period of $1970-2014$ but fluctuated to $17.92 \%$ in 1973-1975 fiscal years. There was a little rise in the trend to $22.36 \%$ in 1976-1978 followed by a sporadic fluctuation in the contribution of export to GDP from $22.03 \%$ in 1979-1981 to $7.59 \%$ in 1982-1984.

Figure 4: A Three-year average \% share of Total Export in GDP (1970-2014) (N'Billion)

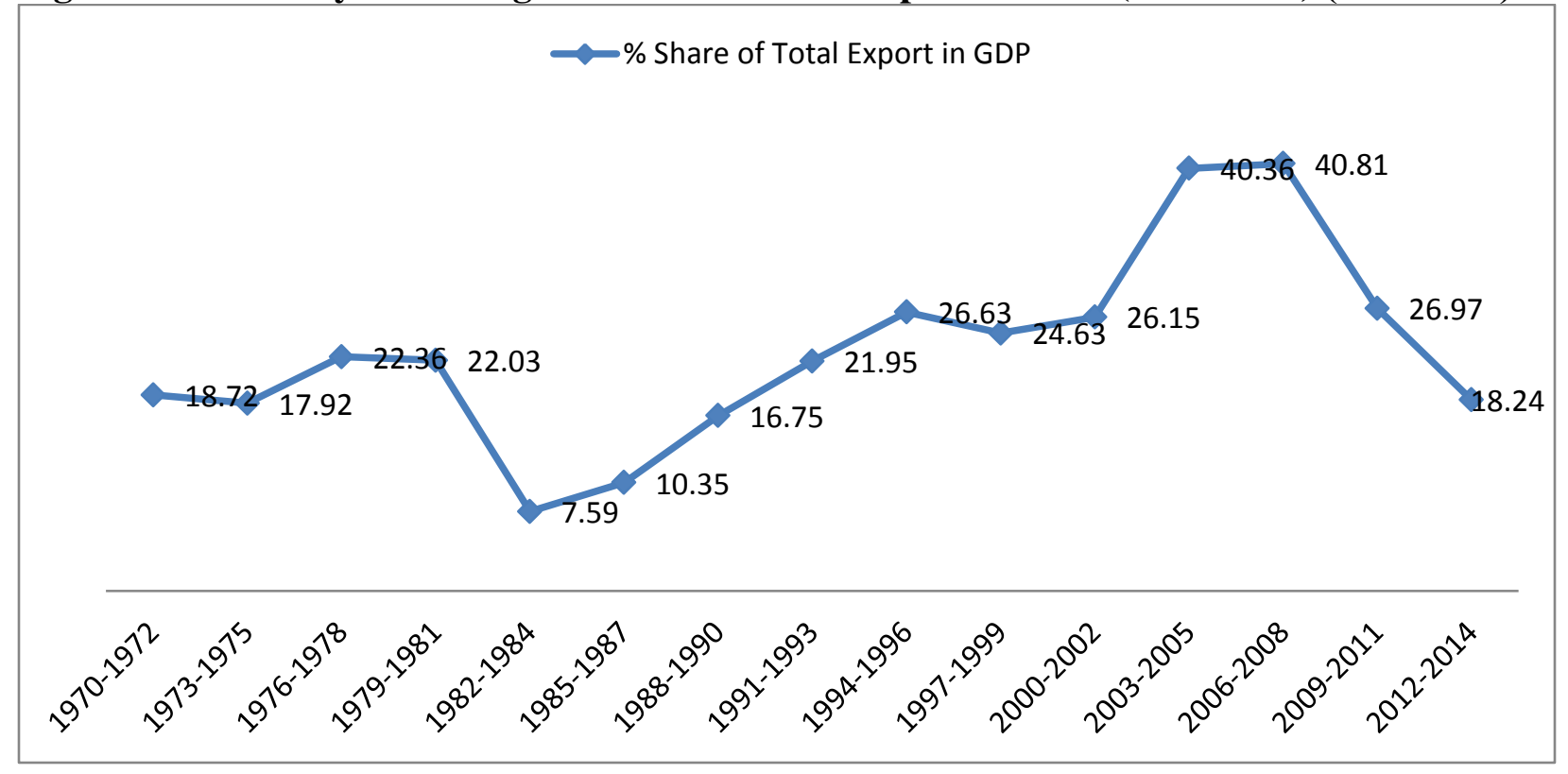

Source: Computed by the authors from the CBN statistical bulletin, 2014 edition.

This sharp decline was orchestrated by the first oil glut which started in 1976 till 1978. The dynamics of export performance however changed (rose) to 10.35\% in 1985-1987 and steadily increased to $26.63 \%$ in 1994-1996. These notable increases may not be unconnected with the impact of the SAP policy which was meant to put the economic structure of Nigeria on a firmfooting. Again, a decline in the quantum of the share of export in GDP fell to $24.63 \%$ in $1997-$ 1999, but it is seemingly true that the emergence of a democratic government in 1999 led to upsurge in export performance as the percentage share of the sector in total GDP rose constantly through the periods of the millennium from $26.15 \%$ in $2000-2002$ to $40.81 \%$ in $2006-2008$. Notwithstanding these rises, the issue of the global financial crises which occurred in the late period of 2007 till the recent episode of the decline in the oil prices has led to steady decline in the share of export in total GDP from $26.97 \%$ in 2009-2011 to $18.24 \%$ in 2012-2014. 


\section{CONCLUSION}

The study has examined the impacts of exchange rate volatility on export demand in Nigeria for the period of 1970-2015 using a descriptive approach. The choice of this period is underscored by the fact that the starting date predates the era of the structural adjustment program (SAP) which is often described as the good days where agricultural and non-oil exports tremendously increased. Again, the chosen date coincides with period when the external trade and exchange rate were indeed liberalized which, thus, the findings of this study will have good implication for export growth in Nigeria.

Empirical analysis showed that in the recent times, there have been declines in the level of the contribution of exports to economic growth (measured by GDP). Therefore, in few years to come, if these trends continue, the economy of Nigeria will experience stunted growth if the mono-cultural emphasis on oil sector is not changed in favour of other non-oil sectors of the economy. This study therefore recommends a deliberate policy action to diversify the structural base of the country's economy to enhance an all-inclusive growth and development. 


\section{REFERENCES}

Abbott A., Darnell, A. and Evans, L. (2001). The Influence of Exchange Rate Variability on UK Exports. Applied Economics Letters, 8(1), 47- 49.

Agolli, M. (2002). Exchange Rate Volatility Effect on Trade Variations. Working Paper, 1-18.

Akinlo, A.E. \& Adejumo, V.A. (2014). Exchange Rate Volatility and Non-oil Exports in Nigeria (1986-2008). International Business and Management, 9(2), 70-79.

Akpokodje, G. \& Omojimite, B. (2009). The Effects of Exchange Rate Volatility on the Imports.

Aliyu, S. U. R. (2008). Exchange Rate Volatility And Export Trade In Nigeria: An Empirical Investigation. Munich Personal RePEc Archive.

Aliyu, S.U. R. (2009a). Exchange Rate Volatility and Export Trade in Nigeria: An Empirical Investigation. Munich Personal RePEc Archive, No. 13490.

Aliyu, S.U. R. (2009b). Impact of Oil Price Shock and Exchange Rate Volatility on Economic Growth in Nigeria: An Empirical Investigation. Munich Personal RePEc Archive., No. 16319.

Anthony, M. (2008). Exchange Rate Volatility and Non-Traditional Exports Performance: Zambia, 1965-1999. African Economic Research Consortium. Nairobi, Kenya .

Aristotelous, K. (2001). Exchange rate volatility, exchange rate regime, and trade volume: evidence from the UK-US export function (1889-1999). Economic Letters, 72, 87-94.

Asseery, A. and Peel, D. (1991). The Effects of Exchange Rate Volatility on Exports. Economics Letters 37, 173-177.

Baak, S. (2004). Exchange Rate Volatility and Trade among the Asia Pacific. International University of Japan, http://repec.org/esFEAM04/up.29293.1080736850.pdf.

Bacchetta, P. and Eric, V. (2000). Does Exchange-Rate Stability Increase Trade and Welfare? The American Economic Review 90(5), 156-170. 
Bailey, M., Tavlas, G. and Ulan, M. (1986). Exchange Rate Variability and Trade Performance: Evidence for the Big Seven Industrial Countries. Weltwirtschaftliches Archive 122(3), 465-477.

Bélanger, D., Gutiérrez, S., Racette, D and Raynauld, J. (1988). The Impact of Exchange Rate Variability on trade Flows: Further Results on Sectoral U.S. Imports from Canada," North American Journal of Economics and Finance 3, 888-92.

Bini-Smaghi, L. (1991). Exchange Rate Variability and Trade: Why is it so difficult to find any Empirical Relationship? Applied Economics 23(1), 927-35.

Broda, C. and John, R. (2003). Identifying the Effect of Exchange Rate Volatility on Trade. Unpublished manuscript, FRBNY and Chicago GSB.

Caballero, R. and Corbo, I. (1989). The Effect of Real Exchange Rate Uncertainty on Exports: Empirical Evidence. The World Bank Economic Review 3(1), 263-78.

Canzoneri, M.B., Peter, B.C., Thomas, C.G. and Michael, P. L. (1984). The Effects of Exchange Rate Variability on Output and Employment. International Finance Discussion Papers, 240.

Cushman, D. O. (1983). The Effects of Real Exchange Rate Risk on International Trade. Journal of International Economics 15(8), 43-63.

Cushman, D. O. (1986). Has Exchange Risk Depressed International Trade? The Impact of Third-Country Exchange Risk. Journal of International Economics 5(9), 361-379.

Dell'Ariccia, G. (1999). Exchange Rate Fluctuations and Trade Flows: Evidence from the European Union. IMF Staff Papers, 46(3), 315-334.

Doganlar, M. (2002). Estimating the impact of exchange rate volatility on export: evidence from Asian countries. Applied Economics Letters, 9(1), 859-863.

Doyle, E. (2001). Exchange rate volatility and Irish-UK trade, 1979-1992. Applied Economics, 33(1), 249-265.

Ethier, W. (1973). International Trade and the Forward Exchange Market. American Economic Review 63, 494-503. 
Franke, G. (1991). Exchange Rate Volatility and International Trading Strategy. Journal of International Money and Finance 10, 292-307.

Frankel, J. and Wei, S. (1993). Trade Blocs and Currency Blocks. Working Paper No. 4335, (Cambridge, Massachusetts: National Bureau of Economic Research).

Gotur, P. (1985). Effects of Exchange Rate Volatility on Trade. IMF Staff Papers, 32, 475-512.

Hondroyiannis, G., Swamy, P., Tavlas, G. and Ulan, M. (2008). Some Further Evidence On Exchange Rate Volatility and Exports. Review of World Economics, 144, 151-80.

Hooper, P. and Mann, C. (1987). The U.S. External Deficit: Causes and Persistence. Federal Reserve Board.

Hooper, Peter and Steven Kohlhagen (1978), The Effect of Exchange Rate Uncertainty on the Prices and Volumes of International Trade, Journal of International Economics, 8 (11): 483-511.

IMF. (1984). Exchange Rate System: Lessons of the Past and Options for the Future. IMF Occasional Paper, No. 30 (Washington: IMF).

Kasman, A. and Kasman, A. (2005). Exchange Rate Uncertainty in Turkey and its Impact On Export Volume. METU Studies in Development, 23, 41-58.

Klein, M. (1990). Sectoral Effects of Exchange Rate Volatility on United States Exports. Journal of International Money and Finance, 9, 299-308.

Koray, F. \& Lastrapes, W. D. (1989). Real exchange rate volatility and US bilateral trade: A VAR approach. Review of Economics and Statistics, 71, 708-712.

Koren, M. \& Adam, S. (2003). Exchange Rate Uncertainty and Export Prices. mimeo, Harvard University.

Krugman, P. (1989). Exchange-Rate Instability. Massachusetts Institute of Technology.

Kumar, V. \& Joseph, A. W. (1991). Exchange Rate Variability and International Trade. Economic Review, Federal Reserve Bank of Atlanta, 37, 17-32. 
Langley, S. V., Guigale, M. Meyers, W. H. \& Hallahan, C. (2000). International financial volatility and agricultural commodity trade: a primer. American Journal of Agricultural Economics, 82, 695- 700.

Lee, K.S. \& Saucier, P. (2005). Exchange rate instability and trade integration -the case of Asia. In: 5th International Conference International Trade and Logistics Corporate Strategies and the Global Economy, LE HAVRE .

Makin, J. H. (1978). Portfolio Theory and the Problem of Foreign Exchange Risk. Journal of Finance 33(5), 517-34.

McKenzie, M. D. (1999). The Impact of Exchange Rate Volatility on International Trade Flows. Journal of Economic Surveys, 13(1), 71-106.

McKenzie, M. D. \& Brooks, R. (1998). The impact of exchange rate volatility on German-US trade flows. Journal of International Financial Markets, Institutions and Money, 7, 73-87.

Medhora, R. (1990). The Effects of Exchange Rate Variability on Trade: The Case of the West African Monetary Union's Imports. World Development, 18(2), 313-324.

Nigerian Export Import Bank. (2009). Nigeria: Brief Profile, Export Import Bank. http://www.gnexid.org/country/Nigeria.

Obiora, K.I \& Igue, N.N. (2006). Exchange rate volatility and U.S-Nigeria trade flows: An econometric appraisal of the evidence. Paper Presented at the 11th Annual Conference of the African Econometric Society. 5th -7th July. Dakar, Senegal.

Olowe, R. A. (2009). Modelling Naira/Dollar Exchange Rate Volatility: Application of GARCH and Asymmetric Models. International Review of Business Research Papers, 5(3), 377-398.

Ogun, O. (1998). Real Exchange Rate Movements and Export Growth: Nigeria, 1960-1990. Research Paper No. 82. African Economic Research Consortium, Nairobi, Kenya.

Omojimite, B. \& Akpokodje, G. (2010). The impact of exchange rate reforms on trade performances in Nigeria. Journal of social sciences. 23(1). 
Peree, E. \& Steinherr, A. (1989). Exchange Rate Uncertainty and Foreign Trade. European Economic Review, 33, 1241-1264.

Rahutami, A. I. \& Kusumastuti, S.Y. (2007). Exchange rate volatility impact to Indonesia Trade: ARDL-ECM Approach. Journal Ekonomi Indonesia, 2.

Tenreyro, S. (2003). On the Trade Impact of Nominal Exchange Rate Volatility. Unpublished, Federal Reserve Bank of Boston.

Tenreyro, S. \& Barro, R. J. (2004). Economic Effects of Currency Unions. NBER Working Paper 9435, National Bureau of Economic Research.

Vergil, H. (2002). Exchange rate volatility in Turkey and its effect on trade flows. Journal ofEconomic and Social Research, 4(1), 83-99.

Yinusa, D. O. \& Akinlo, A. E. (2008). Exchange rate volatility and the extent of currency substitution in Nigeria. Indian Economic Review, 32(2), 161-181. 